\title{
Kentsel-Kamusal Mekânların Kullanılabilirliği Üzerine Bir Araştırma: Nazilli Atatürk Parkı Örneği
}

\author{
Gamze BAYKURT' ${ }^{* 1}$ Barıș KARA ${ }^{2}$ \\ 1,2Adnan Menderes Üniversitesi, Ziraat Fakültesi, Peyzaj Mimarlığı Bölümü, 09010, Aydın, Türkiye
}

(Alınış / Received: 30.09.2020, Kabul / Accepted: 25.03.2021, Online Yayınlanma / Published Online: 15.08.2021)

\author{
Anahtar Kelimeler \\ Kent parkl, \\ Atatürk Parkı, \\ Nazilli
}

\begin{abstract}
Özet: İnsanlar kentlerde rekreasyonel gereksinimlerini karşılayacakları, böylece fiziksel ve ruhsal açıdan yenilenecekleri açık-yeşil alanlara ihtiyaç duyarlar. Kent parkları insanların rekreasyonel gereksinimlerini karşılayan aynı zamanda kentlerin kendilerine özgü yapısal ve bitkisel öğelerini barındıran açık-yeşil alanlardır. Kent parkları ekolojik özellikleri ile kentlilere doğa ile buluşma firsatı sunarken, mekânsal özellikleri ile de fiziksel aktivite olanağı sunmaktadır. Kent parkları aynı zamanda sanatsal ve kültürel faaliyetlerin yapıldığı ve sosyal iletişimin kurulduğu mekânlardır. Bu araştırmada Aydın ili Nazilli ilçesindeki Atatürk Parkı kullanılabilirlik açısından incelenmiştir. Anketlerin yorumlanması ile park kullanıcılarının Atatürk parkı hakkındaki görüşleri, parkla ilgili memnuniyet düzeyleri ve parkın yeterlilik durumuna yönelik düşünceleri değerlendirilmiștir. Araştırma sonucunda, Nazilli'de Atatürk Parkının en çok kullanılan/tercih edilen park olmasının yanı sıra memnuniyeti sağlayamayan özelliklere de sahip olduğu görülmektedir.
\end{abstract}

\section{A Study on The Usability of Urban-Public Spaces: of Nazilli Atatürk Park}

Keywords

Urban park, Atatürk Park, Nazilli

\begin{abstract}
People need open-green spaces in cities where they can meet their recreational needs and thus, they can be physically and spiritually renewed. Urban parks are open-green spaces that meet the recreational needs of people and also contain structural and vegetative elements unique to the cities. While urban parks offer the opportunity to meet with nature with their ecological features, they also offer physical activity with their spatial features. Urban parks are also places where artistic and cultural activities are held and social communication is established. In this study, Atatürk Park in Aydın Province Nazilli district was examined in terms of usability. With interpreting the questionnaires, the views of the park users about the Ataturk Park, their satisfaction level about the park and their opinions about the park's adequacy were evaluated. As a result of the research, it is seen that Atatürk Park in Nazilli is the most used/preferred park as well as having features that cannot provide satisfaction.
\end{abstract}

\section{Giriş}

Günümüzde dünya hızla kentleşmekte ve 2030 yılına kadar dünya nüfusunun \%60'ından fazlasının kentlerde yaşaması beklenmektedir [1]. Kent, bir toplumda yerleşmiş ilişkilerin tümünü yansıtan bir toplumsal ilişkiler kümesidir [2]. Kent nüfusunun artması ve kentlerin sanayileşmesi sonucu kentlilerin doğaya özlemi artarken, açık-yeşil alanlar giderek azalmakta ve doğa ile insanlar arasındaki bağ kopmaya başlamaktadır. Doğadan uzaklaşan insanlar kentleşmenin neden olduğu monoton bir yaşamın sonucu olarak zihinsel, sosyal ve bedensel sorunlar ile baş başa kalmaktadır [3].
Kentin karakterini mimari yapılar ile açık-yeşil alanlar ve bunların birbirleriyle olan karşılıklı etkileşimi oluşturmaktadır. Kentsel açık-yeşil alanlar yalnızca doğayı kentte sembolize etmemektedir. Aynı zamanda bozulan doğa ile insanlar arasındaki bağın dengelenmesinde ve kentlerdeki yaşam kalitesinin artırılmasında önemli bir etkiye sahiptir. Bu nedenle gelişmiş ülkelerde kentsel açık-yeşil alanların nitelik ve nicelikleri yaşam kalitesinin göstergesi olarak kabul edilmektedir. Kentsel açlk-yeşil alanlar işlevselliği ve hayatın bir parçası olmaları nedeni ile kentsel yaşam kalitesini artırmaktadır. Bu bağlamda birçok gelişmiş ülke, insanlar için uygun kentsel mekânların planlamasına yönelerek insanların 
zihinsel ve fiziksel ihtiyaçlarını karşılamayı hedeflemişlerdir [4].

Kentlerdeki açlk-yeşil alanlar, kültürel çeşitliliğin bir arada bulunduğu, doğal süreçlerle meşgul olunduğu, hatıraların korunduğu, yabancılarla buluşulduğu, bir kişinin kalabalığı aşabileceği ya da yalnız olabileceği yerlerdir [5].

Parklar genel anlamda, sınırlı bir kullanım biçimi, esnek bir form özelliği, minimum konstrüksiyon ile maksimum doğal öğeleri kapsayan, dinlenme, eğlenme, spor, serbest oyunlar gibi çeşitli aktif ve pasif rekreasyon gereksinmelerini karşılayan bir yeşil alan türüdür [6, 7]. Park; "estetik, eğitsel, rekreasyonel ve kültürel kullanım için ayrılmış kamusal ya da özel mülkiyete ait alanlardır" [8].

Kent parkları önemli ekolojik, ekonomik, sosyal, estetik ve fiziksel faydalara sahip alanlardır. Doğal ve kültürel öğeler açısından zengin olan kent parkları kentin ekolojisine katkı sağlamaktadır. Kent parkları her yaştan insanın fiziksel gereksinimlerini karşılayan aktif ve pasif rekreasyon olanaklarını barındırmaktadır. Kentlileri doğa ile buluştururken spor yapma, piknik yapma, gibi fiziksel aktivitelere, sanat ve topluluk faaliyetleri gibi kültürel aktivitelere, farklı insanlarla tanışmak gibi sosyal aktivitelere katılmalarına olanak sağlamaktadır [9]. Sosyal açıdan uyumlu, eşitlik ve sosyal dayanışmayı teşvik eden yerler olan kent parkları [5]; kentlilere sağlık ve eğitim konularında katkılar yaparken, yaşamlarını da düzenleme imkânı sunmaktadır [3].

Olmsted'e göre kent parkı, konut bahçelerinden daha geniş, sade ve doğal görünmeli bir koruluk ve orman gibi yoğun bir yeşil dokuya sahip olmamalıdır. $\mathrm{Bu}$ tanımlamaya göre kent parkları, kent halkının zihninde oluşan yapaylığı alıp götüren ve unutturan doğal elemanlar ve kompozisyonlar içermelidir [10].

Son yıllarda, parkların kullanımına yönelik memnuniyet araştırmaları yapılmaktadır. Yapılan bir araştırmada insanların parka gitme ve doğa alanlarını ziyaret etme nedenleri araștırılmıștır. İnsanların en çok dile getirdiği doğaya gitme nedeni katılımcıların \%73'ü tarafından "rahatlamak" olarak belirtilmiştir [11].

Kullanıcı memnuniyetini, kullanıcının rekreasyon alanı içerisinde toplumsal, psikolojik ve fizyolojik rahatsızlıklara uğramadan rekreasyon eylemlerinin verimli olmasına yardım edecek olanakları içeren çevre koşulları etkilemektedir. Kullanıcı memnuniyetini, kullanıcıların kişisel özellikleri, rekreasyon alanının özellikleri ve alanda yer alan faaliyetlerin türü de etkilemektedir [12].

Kullanıcı tipinin kullanıcı memnuniyeti üzerine olan etkilerini inceleyen Hutchison ve Fidel (1984), Hutchison (1987), Joardar (1989) gibi araştırıcılar araştırmalarında; kent parklarında kullanıcı memnuniyetinin yaş, cinsiyet, eğitim seviyesi, gelir durumu ve etnik gruplar gibi kullanıcı tipine göre değiştiğini ortaya koymuşlardır [12].

Diğer yandan kent parkı kullanıcılarının parklardan yeterince faydalanabilmesi için parklardan edindikleri deneyimlerden memnun olmaları gerekmektedir. Bu nedenle kent parkı kullanıcılarının parklardan edindikleri deneyimlere yönelik memnuniyet ve memnuniyetsizlik nedenlerinin bilinmesi, kent parklarından elde edilecek faydaların artmasına ve bu alanların daha sürdürülebilir yönetilmesine katkı sağlamaktadır [13].

Bu araştırmada, Aydın ili Nazilli ilçesindeki Atatürk Parkında yapılan anketler ile kentlilerin parkı kullanım zamanları ve süreleri, parka ulaşım șekilleri, park içerisindeki gördükleri eksiklikler ve memnuniyetleri incelenmiştir. Gözlem formlarının değerlendirilmesi ve anketlerin yorumlanması sonucunda Atatürk parkının geliştirilmesine yönelik öneriler getirilmiştir.

\section{Materyal ve Metot}

Araştırma alanı Aydın'ın Nazilli ilçesinde yer alan Atatürk parkıdır (Şekil 1). Nazilli, Ege Bölgesi'nde Aydın ilinin en fazla nüfusa sahip olan ikinci ilçesidir. Nazilli'de sıcak ve ılıman bir iklim hâkimdir. Nazilli'ye kış aylarında yaz aylarından çok daha fazla yağış düşmektedir. Nazilli ilçesinin yıllık ortalama sıcaklığı $17.4{ }^{\circ} \mathrm{C}$ 'dir. Yıllık ortalama yağış miktarı: $614 \mathrm{~mm}$ 'dir. Bu uygun iklim koşullarından dolayı Nazilli ilçesinde, yaz ve kış aylarında kentsel açı-yeşil alanlar rahatlıkla kullanılabilmektedir. Atatürk parkı Nazilli'nin en işlek caddelerinden biri olan Ordu Caddesi üzerinde yer almaktadır.

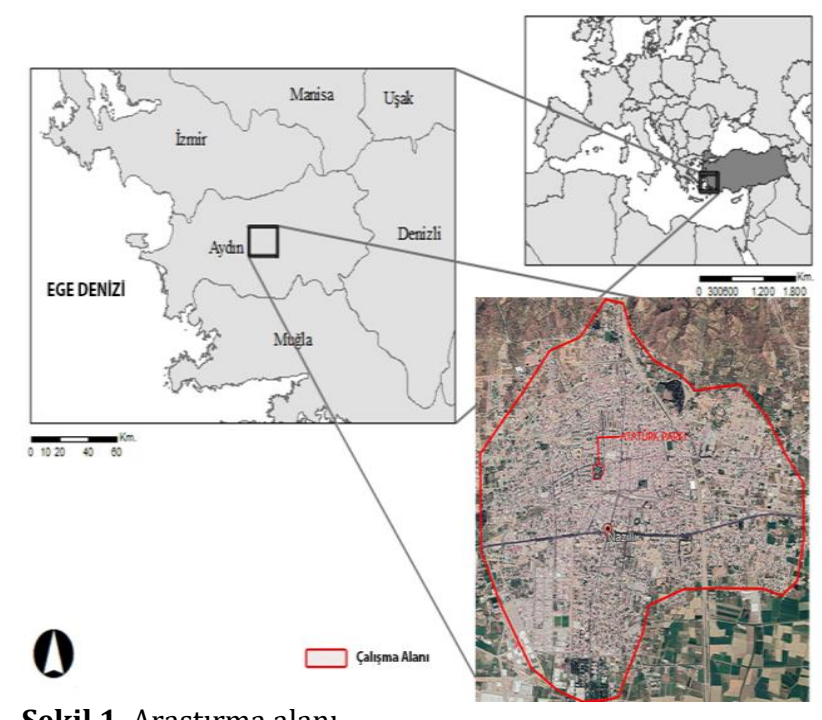

Şekil 1. Araştırma alanı.

Araştırma materyallerini araştırma alanı, araştırma konusu ile ilgili yazılı ve görsel literatür, alan gözlem formları, anketler, alanda çekilen fotoğraflar ve 
Microsoft Office Excel yazılımı oluşturmaktadır. Anket 9'u demografik yapıyl, 16'sl park kullanıcılarının parkı kullanım şekillerini, parkta gördüğü eksiklikleri ve parkı kullanım nedenlerini belirlemeye yönelik olmak üzere olmak toplam 25 sorudan oluşmaktadır.

Araştırma yöntemi büro ve alan çalışması olmak üzere iki aşamadan oluşmaktadır. Büro aşaması; araștırma konusunun ve alan sinırlarının belirlenmesi, literatür taramaları, elde edilen veriler doğrultusunda araștırmanın kuramsal temellerinin oluşturulması, anketin hazırlanması, anket verilerinin düzenlenmesi, anketlerin değerlendirilmesi ve yorumlanması olmak üzere altı alt aşamadan oluşmaktadır.

Alan çalışması ise alan gözlemleri ve anketlerin uygulanması olmak üzere iki alt aşamadan oluşmaktadır (Şekil 2).

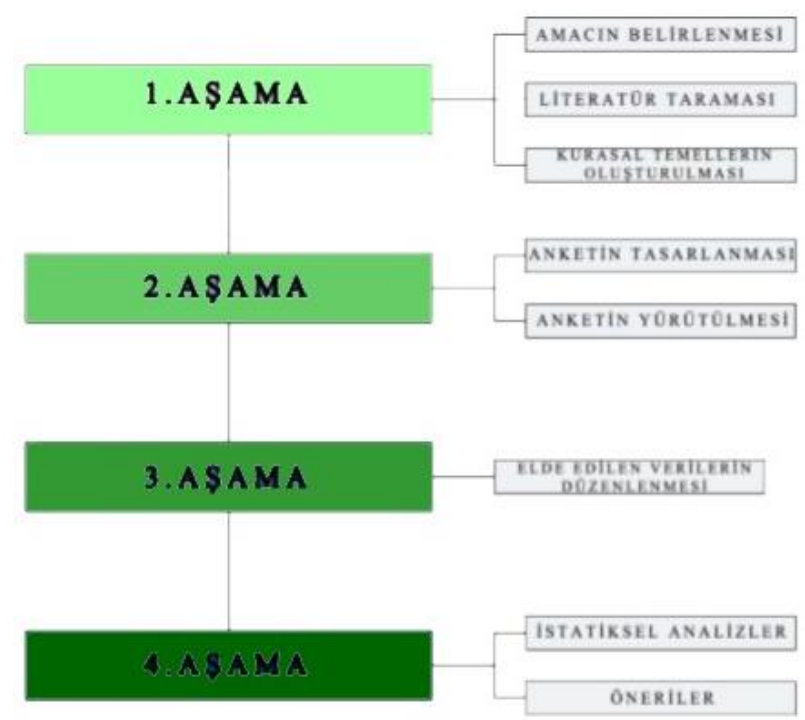

Şekil 2. Araștırma yöntemi akış şeması

Anketler Atatürk parkında 50 kişiye yüz yüze görüşme tekniği ile uygulanmıştır. Anketlerin hazırlanmasında çoktan seçmeli ve 5'li Likert ölçeği kullanılmıștır. Anketler Microsoft Office Excel yazılımı kullanılarak analiz edilmiştir.

\section{Bulgular}

\subsection{Mevcut durum analizi}

Atatürk Parkının kuzeyinde Ordu Caddesi ve 23 Nisan Parkı; doğu, batı ve güneyinde çok katlı konutlar yer almaktadır. Parkın kuzey-doğu, doğu ve güney-batı olmak üzere 3 girişi vardır. Ana giriş (kuzey-doğu); cadde üzerinde olmasından dolayı en çok kullanılan giriștir (Şekil 3). Atatürk Parkı Nazilli'nin en eski parklarından biridir. $18.211 \mathrm{~m}^{2 \prime} \mathrm{lik}$ bir alana sahip

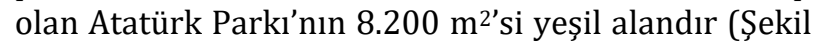
$4)$.

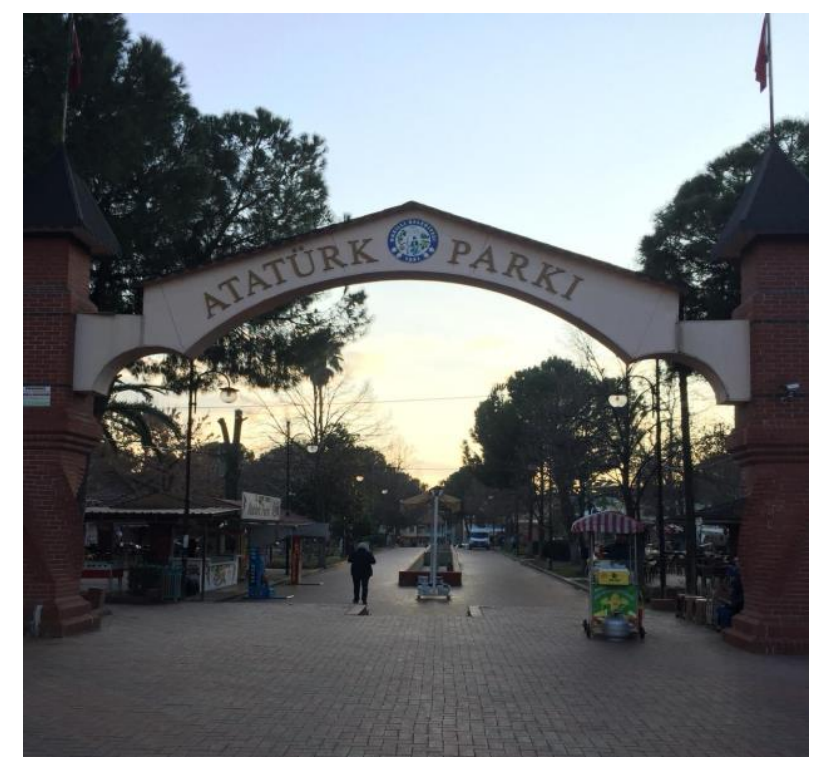

Şekil 3. Atatürk Parkı ana giriși

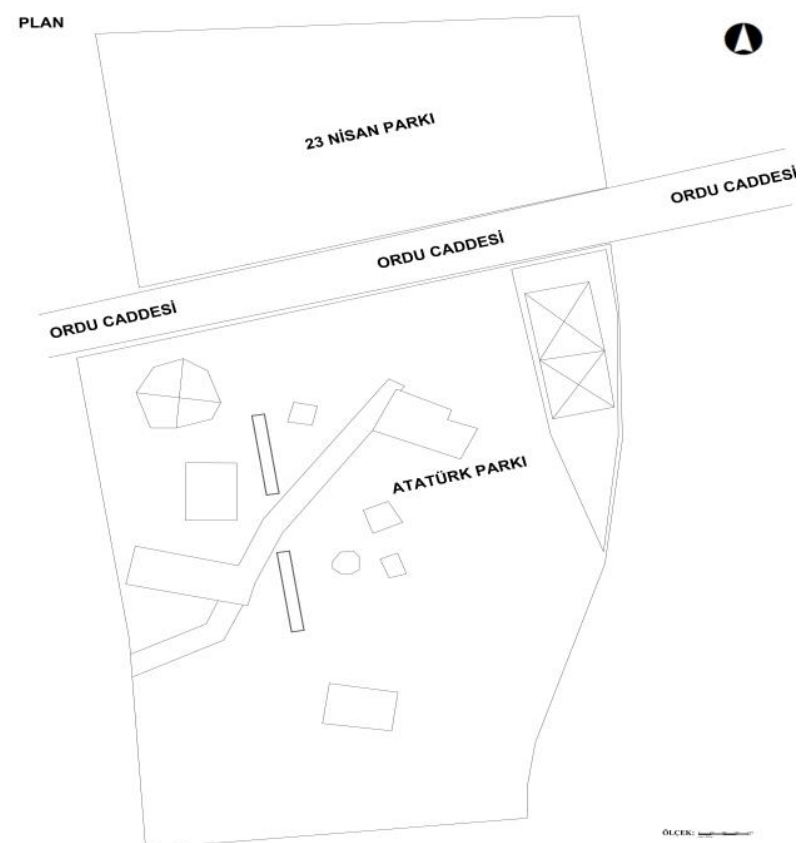

Şekil 4. Atatürk Parkı planı

Parkın ana girişinin batısında yer alan büstler; parka girmeden ilk algllanan, dikkat çeken ve kültürel-tarihi değerlerimizi simgelemektedir (Şekil 5).

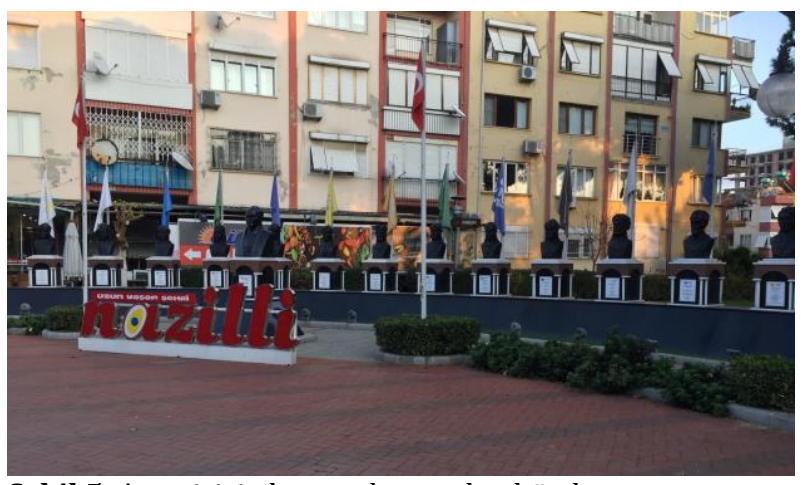

Șekil 5. Ana girișin batısında yer alan büstler 
Atatürk Parkına ulaşım toplu ulaşım, özel araç ve yaya olarak sağlanmaktadır. Park kent merkezinde yer almaktadır. Ulaşımı kolay olan park tüm kente hizmet etmektedir. Park içerisinde farklı yaş gruplarına hizmet eden kullanımlar bulunmaktadır (Şekil 6).

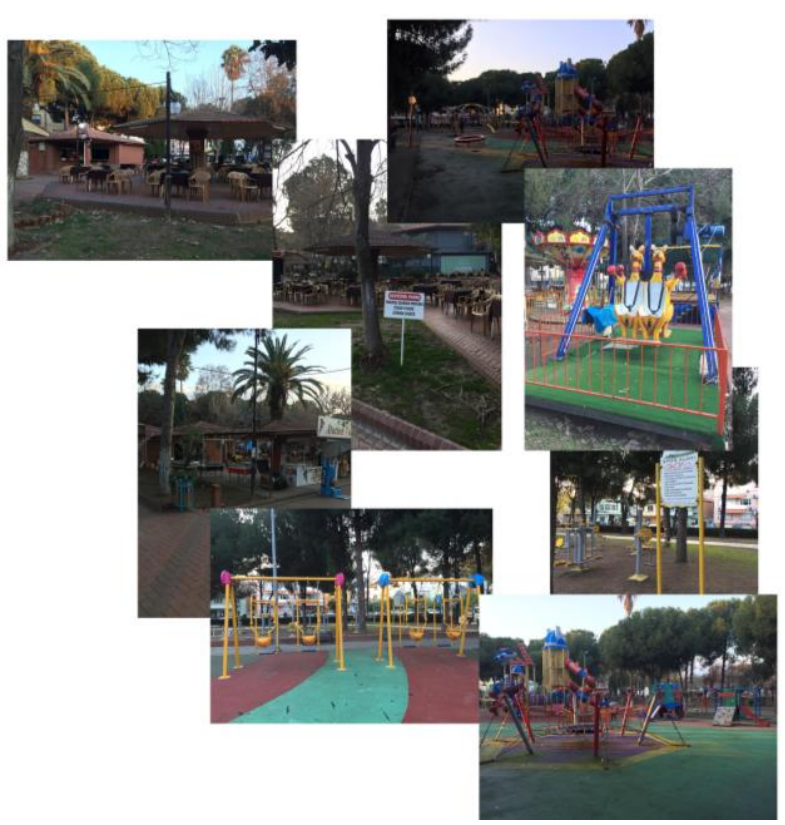

Şekil 6. Farklı kullanıcılara ve yaș gruplarına hizmet eden kullanımlar

Ayrıca Nazilli kent meydanına 227m uzaklıkta olan Atatürk Parkl, meydandan yürüyerek ortalama 7 dakika gibi kısa bir süre içinde ulaşılan bir parktır. Park 3 girişe sahip olduğu için gün içerisinde geçiş noktası olarak da kullanılmaktadır. Giriş sayısındaki fazlalık parkın kullanımını arttırmaktadır. Bunun yanında güneş ışınlarının geliş açısı ve yetişkin bitki varlığı da Atatürk parkının daha fazla tercih edilmesini sağlamaktadır (Şekil 7).

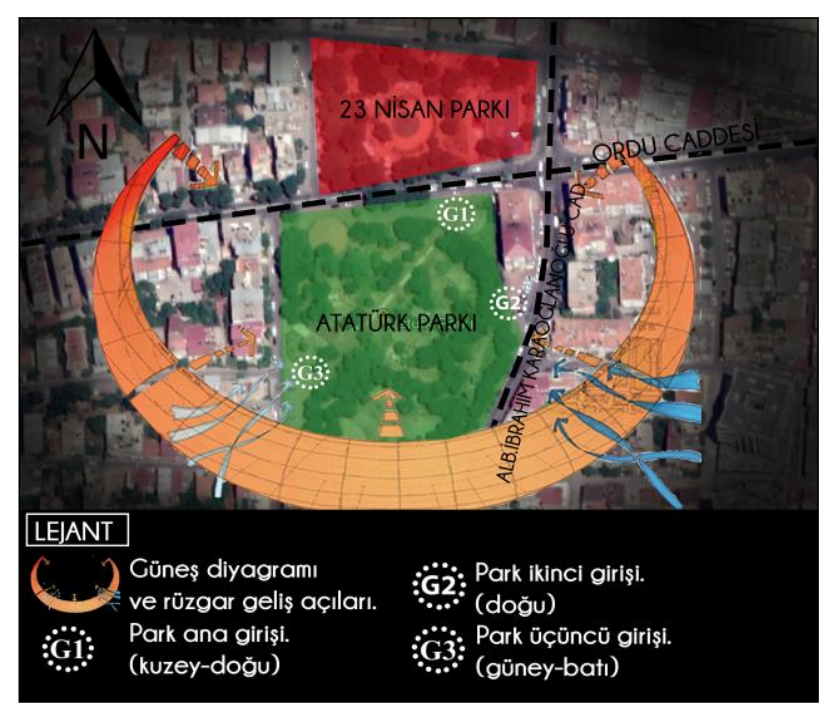

Şekil 7. Atatürk parkı çevre analizi

Ayrıca Atatürk parkının merkezi konumu kent içerisindeki çeşitli kullanım alanlarının bir arada bulunmasına, onları birbirine bağlayarak bütünsellik oluşturmasına ve diğer kentsel kullanımlara karşı da tampon görevi yapmasına olanak sağlamaktadır.

\subsection{Anket çalışmasından elde edilen bulgular}

Ankete katılanların \%50'si (25 kişi) erkek, \%50'si (25 kişi) kadındır. Anket çalışmasına \%64 (32 kişi) oran ile bekar bireyler katılırken, \%36 (18 kişi) oran ile evli bireyler katılmıştır. Katılımcıların \%52'sini (13'er kişi) 19-25 yaş grubu ve 36-45 yaş grubu, \%20'sini (10 kişi) 7-18 yaş grubu, \%28'ini de (7'şer kişi) 26-35 yaş grubu ve 46 yaş üzeri gruptan bireyler oluşturmaktadır. Anket katılımcılarının \%44'ü (22 kişi) öğrenci, \%32'si (16 kişi) memur, \%24'ü (12 kişi) emeklidir. Eğitim durumu bakımından anket katılımclarının \%52'si (26 kişi) üniversite, \%42'si (21 kişi) lise, \%6'sı (3 kişi) ilkokul mezunudur. Ankete katılanların \%52'sinin (26 kişi) herhangi bir geliri yokken, \%26'sının (13 kişi) 2500-3000 TL, \%18'inin (9 kişi) 3500 TL ve üzeri, \%4'ünün ise (2 kişi) 1000-2000 TL geliri vardır.

Nazilli'de en sık ziyaret edilen parklar sorulduğunda kullanıcıların \%84'ü (42 kişi; 20 erkek-22 kadın), "Atatürk Parkı" cevabını verirken, \%6'sı (3 kişi; 2 erkek-1 kadın) "Sümer park" cevabını vermiştir. Nazilli'deki parkların yeterliliği sorusuna ise ankete katılanların \%96'sı (48 kişi; 20 erkek-28 kadın) "Yeterli" olarak cevaplandırmıştır. Atatürk Parkını genel olarak değerlendiriniz sorusuna kullanıcıların \%92'si (46 kişi; 21 erkek-25 kadın) "Kararsızım" cevabını verirken, \%6'sı (3 kişi; 1 erkek-2 kadın) "Yeterli" cevabını vermiş ve \%2'si (1 kişi; 1 erkek) "Yetersiz" cevabını vermiștir. Atatürk parkına ulașım şekli sorulduğunda anket katılımcıların \%94'ü (47 kiși; 26 erkek-21 kadın) "Yaya" cevabını verirken, \%2'si (1 kişi; 1 erkek) “Bisiklet" şeklinde cevaplandırmıştır. Parktaki genel kullanıcı memnuniyetini sorulduğunda \%42 (21 kişi; 8 erkek13 kadın) kararsızım, \%10'u (5 kişi; 3 erkek-2 kadın) memnunum cevabını vermiştir (Tablo 1 ).

Tablo 1. Atatürk Parkının genel değerlendirilmesi.

\begin{tabular}{ccccc}
\hline & \multicolumn{4}{c}{$(\%)$} \\
En sık ziyaret edilen & $1^{*}$ & $2^{*}$ & $3^{*}$ \\
parklar & 6 & 10 & 84 & \\
Parkların yeterliliği & 4 & 96 & - & \\
Parkın genel durumu & 2 & 6 & 92 & \\
& & Toplu & Yaya & \\
Parka ulaşım şekli & Bisiklet & taşıma & & \\
& 2 & 4 & 94 & \\
Memnuniyet düzeyi & $\mathrm{A}$ & $\mathrm{B}$ & $\mathrm{C}$ & $\mathrm{D}$ \\
& 16 & 32 & 42 & 10 \\
\hline
\end{tabular}

1*: Sümer Park, 2*: 23 Nisan Parkı, 3*: Atatürk Parkı.

A: Hiç memnun değilim, B: Memnun değilim, C: Kararsızım, D: Memnunum

Ankete katılanların \%34'ü (17 kişi; 9 erkek-8 kadın) serbest zamanlarını "Arkadaşlarla buluşma", \%4'ü (2 kiși; 2 kadın) "Kitap okuma” ile değerlendirmektedir (Tablo 2). 
Tablo 2. Kullanıcların serbest zaman değerlendirme șekilleri

\begin{tabular}{cc}
\hline Serbest zaman değerlendirilme şekli & $(\%)$ \\
\hline Arkadaşlarla buluşma & 34 \\
Kitap okuma & 4 \\
Diğer & 36 \\
Serbest zamanım yok & 26 \\
\hline
\end{tabular}

Atatürk Parkının kullanım durumunun belirlenmesine yönelik kullanıcıların parkı kullanım sıklığı incelendiğinde anket katılımclarının \%54'ü (27 kişi; 12 erkek-15 kadın) "Ayda 1-2 kez", \%10’u (5 kişi; 3 erkek-2 kadın) ise "Yılda 1-2 kez" kullandıklarını belirtmiștir. Parkı, kullanıcıların \%58'i (29 kişi; 15 erkek-14 kadın) “Hafta sonu”, \%20’si (10 kiși; 2 erkek-8 kadın) de "Her zaman" kullanmaktadır. Parkı, kullanıcıların \%62'si (31 kiși; 14 erkek-17 kadın) "Yaz", \%2'si (1 kişi; 1 erkek) ise "Kış" aylarında ziyaret etmektedir. Parkta kullanıcılarının \%54'ü (27 kişi; 11 erkek-16 kadın) "1-3 saat", \%2'si (1 kişi; 1 kadın) ise "3-saat" den fazla bulunmaktadır (Tablo 3).

Tablo 3. Atatürk Parkının kullanım durumu

\begin{tabular}{|c|c|c|c|}
\hline & \multicolumn{3}{|c|}{$(\%)$} \\
\hline \multirow{3}{*}{ Kullanım sıklığı } & Haftada & Ayda 1-2 & Yılda 1-2 \\
\hline & $1-2 \mathrm{kez}$ & kez & kez \\
\hline & 36 & 54 & 10 \\
\hline \multirow{2}{*}{$\begin{array}{l}\text { Kullanım zamanı } \\
\text { (Hafta) }\end{array}$} & Hafta içi & $\begin{array}{l}\text { Hafta } \\
\text { sonu }\end{array}$ & Her zaman \\
\hline & 22 & 58 & 20 \\
\hline \multirow{2}{*}{$\begin{array}{l}\text { Kullanım zamanı } \\
\text { (Mevsim) }\end{array}$} & Yaz & Kış & $\begin{array}{c}\text { Her } \\
\text { mevsim }\end{array}$ \\
\hline & 62 & 2 & 36 \\
\hline Kullanım süresi & $\begin{array}{c}-1 \text { sa. } \\
44\end{array}$ & $\begin{array}{c}1-3 \mathrm{sa} . \\
54\end{array}$ & $\begin{array}{c}\text { 3-sa. } \\
2\end{array}$ \\
\hline
\end{tabular}

Parktaki bitkilendirmenin önemi sorulduğunda ankete katılanların tamamı bitkilendirmeyi (\%100/50 kişi; 23 erkek-27 kadın) çok önemli olarak ifade etmiștir. Yeșil dokunun yeterliliği sorulduğunda ise \%88'lik (44 kişi; 15 erkek-29 kadın) bölüm yeterli bulmadığını belirtmiştir. Parktaki donatı elemanlarının yeterliliği ile ilgili soruyu katılımcıların \%52'si (26 kişi; 10 erkek-16 kadın) "Yetersiz" şeklinde cevaplandırmıştır. Atatürk parkında hangi donatı elemanlarının eksik olduğu sorusuna ise \%38 (19 kişi; 10 erkek-9 kadın) oranda "Bank", \%20 (10 kiși; 4 erkek-6 kadın) oranda "Aydınlatma elemanı" cevabı verilmiștir (Tablo 4).

Tablo 4. Atatürk Parkının yeșil doku ve donatı yeterliliği

\begin{tabular}{lcccc}
\hline & \multicolumn{4}{c}{$(\%)$} \\
\hline Bitkilendirme & \multicolumn{2}{c}{ Önemsiz } & Çok önemli \\
önemi & \multicolumn{2}{c}{-} & & 100 \\
& Yetersiz & Yeterli & & \\
Yeşil doku yeterliliği & 88 & 12 & & \\
Donatı yeterliliği & 52 & 48 & & \\
Eksik donatı & Aydınlatma & Çöp & Bank & Diğer \\
elemanları & elemanı & kutusu & & \\
& 20 & 24 & 38 & 18 \\
\hline
\end{tabular}

Atatürk Parkı ankete katılanların \%36'sı (18 kişi; 8 erkek-10 kadın) tarafından buluşma noktası olarak, \%24'ü (12 kiși; 5 erkek-7 kadın) tarafından rekreasyon ve parktaki aktiviteler, \%18'i (9 kişi; 5 erkek-4 kadın) tarafından da sosyalleşme nedeni ile tercih edilmektedir (Tablo 5).

Tablo 5. Atatürk Parkının tercih edilme nedenleri

\begin{tabular}{cc}
\hline Tercih edilme nedenleri & $(\%)$ \\
\hline Buluşma noktası & 36 \\
Rekreasyon-parktaki aktiviteler & 24 \\
Sosyalleşme & 18 \\
Piknik yapmak & 10 \\
Diğer & 12 \\
\hline
\end{tabular}

Parkın beğendiğiniz yönleri nelerdir? sorusuna, en fazla verilen cevaplar "konumu-büyüklüğü" (\%66/33 kiși; 13 erkek-20 kadın) ve "geniş-ferah" olmasıdır (\%24/12 kiși; 6 erkek-6 kadın). Parkın beğenmediğiniz yönleri nelerdir? sorusuna ise en fazla verilen cevaplar işletme çalışanları (\%58/29 kişi; 10 erkek-19 kadın), servisin yavaş olması (\%30/15 kişi; 8 erkek-7 kadın) ve fiyatların pahalı olmasıdır (\%12/6 kişi; 4 erkek-2 kadın).

Parktaki memnuniyet/memnuniyetsizlik kriterleri sorulduğunda Atatürk Parkının kirli ve bakımsız olması (\%92/46 kişi; 17 erkek-29 kadın), engelli kullanımına uygun olmaması (\%84/42 kişi; 22 erkek20 kadın), yönlendirme panolarının yetersiz olması (\%94/47 kişi; 25 erkek-22 kadın) konularında memnuniyetsizliklerini ifade etmişlerdir (Tablo 6).

Atatürk parkının sessiz ve huzurlu olması (\%52/26 kişi; 10 erkek-16 kadın), yakın ve ulaşılabilir olması (\%90/45 kişi; 22 erkek-23 kadın), çocuk oyun alanına sahip olması (\%70/35 kişi; 13 erkek-22 kadın) ise memnuniyet unsurları olarak belirtilmiştir (Tablo 6).

Tablo 6. Atatürk Parkının memnuniyetsizlik nedenleri

\begin{tabular}{|c|c|c|c|c|c|}
\hline & \multicolumn{5}{|c|}{$(\%)$} \\
\hline $\begin{array}{l}\text { Memnuniyetsizlik/ } \\
\text { Memnuniyet }\end{array}$ & 1 & 2 & 3 & 4 & 5 \\
\hline Temiz ve bakımlı olma & - & 92 & 8 & - & - \\
\hline $\begin{array}{l}\text { Spor ve egzersiz yapma } \\
\text { olanağl }\end{array}$ & - & 20 & 64 & 16 & - \\
\hline Sessizlik ve huzur & - & 18 & 30 & 52 & - \\
\hline Güvenlik sorunları & - & - & 54 & 26 & 20 \\
\hline $\begin{array}{l}\text { Yakınlık ve ulaşım } \\
\text { kolaylığı }\end{array}$ & - & - & - & 10 & 90 \\
\hline $\begin{array}{l}\text { Engelli kullanımına uygun } \\
\text { olmama }\end{array}$ & - & 6 & - & 10 & 84 \\
\hline $\begin{array}{l}\text { Sosyal ve kültürel aktivite } \\
\text { olanağl }\end{array}$ & - & 16 & 66 & 18 & - \\
\hline $\begin{array}{l}\text { Kafe ve restoran } \\
\text { sayısındaki yetersizlik }\end{array}$ & - & 14 & 80 & 6 & - \\
\hline $\begin{array}{l}\text { Yönlendirme panosu } \\
\text { sayısındaki yetersizlik }\end{array}$ & - & - & - & 6 & 94 \\
\hline Çocuk oyun alanı olması & - & - & 16 & 70 & 14 \\
\hline $\begin{array}{l}\text { Otopark sayısındaki } \\
\text { yetersizlik }\end{array}$ & - & 20 & 50 & 30 & - \\
\hline
\end{tabular}

1: Kesinlikle Katılmıyorum, 2: Katılmıyorum, 3: Kararsızım, 4: Katılıyorum, 5: Kesinlikle Katılıyorum 


\section{Tartışma ve Sonuç}

Kent parklarının planlanması ve tasarımı aşamasında kullanıcıların özelliklerinin, isteklerinin ve beklentilerinin de araştırılması gerekmektedir.

Kent parkları kentlilerin katılımları ile planlandı̆̆ında ve tasarlandığında kentlilerin gereksinimlerini karşılayan mekânlar olmaktadır. Peyzaj mimarları bu süreçte önemli katkılar sunmaktadır. Rekreasyonel gereksinimlerin karşılandığı kent parkları toplumun her kesimine aynı oranda kullanım imkânı sağlamalıdır [14].

Kullanıcıların memnuniyet düzeyi ne kadar fazla olursa parklar o kadar çok kullanılmakta ve benimsenmektedir. Bu şekilde güvenlik sorunlarının da azalması sağlanmaktadır.

İyi planlanmış ve tasarlanmış bir parkın ulaşımı kolay olmalı ve günün farklı saatlerinde her yaştan kullanıcıya hizmet etmelidir.

Kolay erişilebilir ve her yaştan kullanıcı için çekici olacak şekilde tasarlanmış kent parklarının varlığı, fiziksel aktiviteyi kolaylaştırıp stresi hafifleterek kronik hastalık riskini azaltmaktadır [15].

Karadeniz (2019) yapmış olduğu çalışmada peyzaj tasarım kriterleri açısından Samsun kent parklarını incelemiştir. Çalışma sonunda insanların parkları daha çok sosyal aktivite için tercih ettiği sonucuna ulaşırken, parkların engelli kullanımı açısından uygun olmadığı sonucuna ulaşılmıştır [16]. Yapılan bu çalışmanın sonuçları bulunan sonuçlar ile benzerlikler göstermektedir. Karakaya ve Cengiz (2019) yaşam kalitesinin artırılmasında parkların rolünün belirlenmesi amacıyla Eskişehir'de çalışma yapmışlardır [17]. Altuntaş (2020) yapmış olduğu çalışmada tabiat parklarını kullanıcı memnuniyeti açısından değerlendirmiş ve kullanıcıların büyük bir kısmının memnuniyet duyduğunu tespit etmiştir [18]. Kocalar (2016) yapmış olduğu çalışmada parkların etkinlik mekânı ya da bilgilendirme sahası olarak etkin rollere sahip olduğunu tespit etmiştir [19]. Bu araştırma sonucunda da parklarda rekreasyonel faaliyetlerinin yetersiz olduğu ve artırılmasının parklara olan tercihleri artıracağı tespit edilmiştir. Bu çalışmada kullanıcıların Nazilli'deki kent parkları hakkında memnuniyetlerinin belirlenmesi amaciyla anket çalışmaları ve yüz yüze görüşmeler gerçekleştirilmiştir. $\mathrm{Bu}$ yöntemler kullanılarak insanların belirli konulara karşı duygu ve düşünceleri kısa sürede tespit edilebilmektedir.

Soydan (2020) çalışmasında Niğde kent merkezinde bulunan parkların kullanıcı memnuniyeti açısından değerlendirilmesini amaçlamıştır [20]. Özellikle parklarda rekreasyonel faaliyetler açısından çok fazla sayıda eksikliklerin bulunduğu tespit edilmiştir. Bu yüzden parklarda bulunan rekreasyonel faaliyetlerin sayısı artırılmalıdır. Parklara tırmanma alanları, uçurma faaliyetleri, maket yapım alanları oyuncak müzesi vb. faaliyetler getirilerek kullanıcıların parkları daha fazla tercih etmesi sağlanabilir.

Parkların bitkisel tasarımında kullanılan bitkiler seçilirken renk, doku vb. özellikler ile uyum ya da zitlık oluşturacak türler tercih edilmelidir. Bu şekilde parkların görsel kalitesi artırılabilmektedir. Parklar sadece günün belirli saatlerinde kullanılan alanlar olmamalıdır. Gündüz olduğu gibi akşam saatlerinde de parkların kullanımı sağlanmalıdır. Bunun için de iyi bir aydınlatma tasarımına ihtiyaç duyulmaktadır. Aydınlatma tasarımı yapılırken sadece güvenlik kaygısı düşünülmemeli, estetik unsurlar da düşünülmelidir. $\mathrm{Bu}$ sayede kullanıcıların parkları akşam da kullanması sağlanabilmekte ve memnuniyet düzeyleri artırılabilmektedir.

Parklar tasarlanırken toplumun tüm kesimlerinin bu alanları kullanacağı unutulmamalıdır. Özellikle engelli bireyler açısından uygun tasarımlar yapılmalıdır. Bu konuda karşılaşılan en büyük sorun ise parkların erişilebilirliği konusudur. Bu yüzden parkların planlama aşamasında yer seçimi, tasarım aşamasında ise yolların, donatı elemanlarının ve oturma birimlerinin genişlikleri ve yüksekliklerinin engelli bireylerin kullanımı açısından uygun tasarlanması gerekmektedir. Kentsel donatı elemanlarında; her bir kentsel donatı elemanı için ayrı bir aydınlatma tasarımı düşünülmeli, böylece parklar daha da çekici duruma getirilebilmektedir. Kullanıcı memnuniyeti ilerleyen zamanla değişebilen bir kavramdır. Sonuç olarak Niğde kent parklarının kullanıcı memnuniyetini kısmen sağladığı tespit edilmiştir. Yapılacak olan düzenlemelerle parklara olan tercihler artırılabilir sonuçlarına ulaşmıştır [20]. Bu çalışmada da benzer nedenlerden dolayı Atatürk Parkı kullanıcıları tamamen memnun değillerdir. Soydan (2020)'nin getirdiği öneriler bu çalışmada getirilen önerilerle benzerlik göstermektedir [20].

Vural (2020) çalışmasında; bir parkın niteliğinin fonksiyon alanlarının çeşitliliği ve ihtiyacı karşılama düzeyi ile doğrudan ilişkili olduğunu belirtmiş̧tir [21]. $\mathrm{Bu}$ kapsamda katılımcıların yapmış olduğu değerlendirmede fonksiyonel yapı ile fiziksel/mekânsal yapının kullanıcı memnuniyetini sağlamada oldukça yetersiz kaldıkları görülmektedir. Katılımcıların fonksiyon alanlarının yeterliliği ile ilgili 1-5 puan arasında yapmış olduğu değerlendirmenin 1,66 ile 2,73 puan arasında gerçekleștiği, ortalamalarının ise 2,07 olduğu görülmüştür sonucuna varmıştır [21]. Ancak bu çalışmada Atatürk parkını kullanıcıları parkın eksiklikleri olmasına rağmen her yaş grubuna hizmet edebilen bir park olarak nitelendirilmiş ve mekânsal anlamda bir sorun yaşanmadığı sonucuna varmışlardır.

Çetinkaya ve ark. (2015), çalışmasında park kullanıcılarının memnuniyetinin etkileyen en önemli 
faktörün ulaşlabilirlik faktörü olduğunu tespit etmiştir [13]. Bu bulgusunu ise Aksoy ve Akpınar'ın (2011) park alanının tercih edilmesini etkileyen en önemli faktörün park alanlarının yakınlığı olduğu bulgusu ile de desteklemiştir [22]. Ayhan ve Atabeyoğlu (2020), çalışmasında ulaşılabilirlik ile ilgili olarak oldukça olumlu sonuçlar elde etmiştir [23]. Yücedağ ve ark. da (2018) Denizli Pamukkale'deki kent parklarının [24], Kaya ve ark.'da (2019) Antalya-Dokuma Parkının kente yürüme mesafesinde olmalarından dolayı kullanıcıların parkları büyük ölçüde yürüyerek ziyaret ettiklerini belirtmişlerdir [25]. Bu sonuçlarda, Atatürk parkının ziyaretçilerin büyük bir bölümü tarafından yaya olarak ziyaret edildiği sonucu ile örtüşmektedir.

Köksaldı ve Turkan (2020), kent parkları yalnızca kullanıcıların rekreaktif ihtiyaçlarının karşılanmasına odaklanmamalı, bu alanların kent yaşamında; eğitim çalışmaları, kültürel ve sanatsal etkinlikler, spor faaliyetleri, bilimsel çalışmaların gerçekleşmesi içinde önem arz ettiğinin bilincinde olunmalıdır çıkarımında bulunmuşlardır [26]. Bu çalışmada da Atatürk Parkının rekreasyon ihtiyaçlarını karşılaması yanında, daha kapsamlı bir çalışma dahilinde, park için memnuniyet derecesini daha da arttırıcı planlama-tasarım çalışmalarının yapılması önerilmektedir.

Anket sonuçları kullanıcıların Nazilli'de en fazla Atatürk parkını tercih ettiklerini ortaya koymuştur. Parkın en fazla tercih edilme nedenlerinin konumu ve ulaşımının kolay olmasıdır. Parkın Nazilli kent merkezinde yer alması ulaşımını kolaylaştırmakta ve kullanımını artırmaktadır. Bu nedenle kullanıcıların tamamina yakını parkı yaya olarak ziyaret etmektedir. Kullanıcılar Atatürk Parkından genel olarak memnun değildir. Bu memnuniyetsizlik Tablo 6'da ortaya konulmuştur. Parkın yüksek oranda temiz ve bakımlı olmaması, tam anlamıla güvenliğin sağlanamayıp güvenlik sorunlarının olması, sosyal ve kültürel aktivite olanağının yeteri kadar bulunmaması, kafe ve restoran sayısının az olması, vb. eksiklikler parkın genel anlamda memnuniyet derecesini düşürmektedir. Tüm bunlara rağmen Atatürk pakında memnuniyet içeren konular da bulunmaktadır. Memnuniyet derecesi yüksek konular da parkın kullanılabilirliğini arttırıcı yönde etki etmiştir.

Kentsel gelişim için sürdürülebilirlik göstergeleri daha fazlasını içermelidir. Bunun için kamusal alanlar ve açık yeşil alanlarla ilgili kent parklarının parametreleri yanı sıra özellikle vatandaşların memnuniyetini yansitan dizinlerin algılanması gerekmektedir [27].

Atatürk parkının yaz aylarında yoğun olarak kullanılmasının en önemli nedeni farklı kullanıcı gruplarının gereksinimlerini karşılayan aktiviteleri barındırmasıdır. Nazilli'nin iklim koşulları nedeni ile de park yıl boyunca yoğun olarak kullanılmaktadır.
Kent parklarının kullanıcılara farklı rekreasyonel faaliyetleri bir arada sunması park kullanıcılarının kullanım sürelerini arttırarak, kullanıcı memnuniyetini olumlu yönde etkilemektedir [28].

Kent içindeki yeşil alanlar, araç trafiğini, yaya, rekreasyon ve yerleșim alanlarından ayırmakla insanlar için trafik yönünden gereken güvenceyi sağlamış olurlar [29]. Ayrıca yeterli büyüklük ve sayıdaki açık alanlar kentin aşırı büyümesine karşı da tampon görevi yapar [30]. İstenmeyen görüntüler ve ulaşımlar için sınır, engel ve perde oluştururlar. Yeşil kuşaklar halinde kent gelişimini denetleyerek kontrolsüz büyümesini engellemek için tampon görevi yapmaktadır. Aynı zamanda kent çevresinde tarımsal üretime de olanak sağlamaktadır [31].

Tüm bunlar çerçevesinde Atatürk Parkına dair yerinde yapılmış olan gözlem ve uygulanan anket çalışmaları sonucunda yenilenmesine dair öneriler şu şekilde sıralanabilir;

- Atatürk parkının fonksiyonel yapısının çeşitlendirilmesi, parkta bulunan canlı ve cansız materyalin nitelik ve nicelik bakımdan iyileştirilmesi memnuniyet derecesini yükseltecektir.

- Memnuniyetsizlik içeren konular istenilen şekilde karşılanırsa Atatürk Parkının memnuniyet derecesi daha da artacak ve daha çok tercih edilecektir, Bu gelişmenin sonucunda, Nazilli kenti için bir gelişim süreci başlamış olacak, Atatürk Parkında olan gelişmeler diğer parklar için de rehber olacaktır. Parktaki güvenlik sorunları; gece kullanım için özellikle aydınlatma elemanları sayısının arttırılması ve gece-gündüz tüm kullanımlar için gerekirse güvenliğini sağlayacak güvenlik görevlileri parkın 3 girişine de yerleştirilmelidir.

- Kafe-restoran ve spor-egzersiz alan sayısı arttırılarak hem kullanıcı sayısında artış olacak hem de kullanıcıların yetersiz gördükleri sosyal ve kültürel aktivite olanakları geliştirilmiş olacaktır.

- Parklarda tasarım ve planlama yapılma aşamasında, toplumdaki her türlü kullanıcıya hitap etmesi gerektiği unutulmaması gereken bir konudur. Fakat Atatürk parkında bu konu göz ardı edilmiştir. Engelli bireyler için Atatürk parkındaki memnuniyetsizlik dikkat çekmektedir. Bu yüzden parkın engelli kullanımına uygun hale gelebilmesi için çalışmalar yapılmalıdır.

- Atatürk parkında bir başka rahatsızlık duyulan konu ise; işletme çalışanlardır. Çalışanlarla ile ilgili sorunlar çözülmeli, özellikle de temizlik ve bakım konusunda belediye ve işletme sahipleri daha dikkatli olmalı, parkın temizliğine özen göstermelilerdir. Parkın içerisine temizlik konusunda uyarıcı tabelalar yerleştirilerek ve çöp 
kutusu sayısı arttırılarak park kullanıcılarının memnuniyeti arttırılabilir. Böylece parkın kullanılabilirliğinin de artması öngörülmektedir.

- Ayrıca Atatürk parkı bitkilerinin korunması ve iklime uygun doğal bitki türlerinin de eklenmesiyle park daha da ekolojik bir kimlik kazanacak ve kullanımı artacaktır.

Sonuç olarak; giderek betonlaşan kentlerin arasında yaşayan insanların yaşadıkları olumsuzlukları üzerlerinden atabilmeleri için yeşil alanlara ihtiyacı vardır. Kent parkları da bu ihtiyacı karşılayabilen, farklı yașam tarzlarından ve kültürden insanların sosyalleştikleri, dinlendikleri, eğlendikleri alanlardır. $\mathrm{Bu}$ alanlar aynı zamanda kentlere birçok işlev kazandırmasının yanında ekolojik ișlevlilik de kazandırır. Özellikle bu ekolojik ișlev kent ve kent parkları için önemlidir. Ayrıca kentlerde yaşam kalitesini olumlu etkileyen ve kent içerisinde ekolojik-estetik dengenin sağlanmasında önemli işlevleri bulunan kent parkları diğer açık yeşil alanlar içerisinde öncelikli alanlardır. Kamu yararına yapılan kent parkları bulundukları çevrenin değerini direkt olarak etkilemektedir. Kent parkları hem kent hem de kentliler için çok önem arz eden açık yeşil alanlar içerisindedir. Atatürk parkı da tüm bu nitelikleri taşıdığından dolayı Nazilli kenti için önemli bir kent parkıdır. Çalışmada yapılan anketler sonucunda olumsuzluklar değerlendirilip giderilirse ve memnuniyet taşıyan nitelikler korunup geliștirilirse daha fazla sayıda kullanıcıya hitap edecek ve kullanılabilirlik oranı olumlu yönde artıș gösterecektir. Bunlar da beraberinde Nazilli kentinin en eski parklarından biri olan Atatürk Parkının kalıcılığını arttıracaktır, bu da kente büyük ölçüde manevi değer kazandıracak ve ekolojik olarak olumlu yönde artış göstermiş olacaktır.

\section{Etik Beyanı}

Bu çalışmada, "Yükseköğretim Kurumları Bilimsel Araştırma ve Yayın Etiği Yönergesi" kapsamında uyulması gerekli tüm kurallara uyulduğunu, bahsi geçen yönergenin "Bilimsel Araștırma ve Yayın Etiğine Aykırı Eylemler" başlığı altında belirtilen eylemlerden hiçbirinin gerçekleștirilmediğini taahhüt ederiz.

\section{Kaynakça}

[1] Bolund, P. Hunhammar, S. 1999. Ecosystem Services in Urban Areas. Ecological Economics, 29, 293-301.

[2] Harvey, D. 2013. Sosyal Adalet ve Şehir. Metis Yayınları, 294, İstanbul.

[3] Önal, S., Sağır, Ö. 2018. Ankara Kent Parklarının Kullanımının Belirlenmesi. Ankara Araştırma Dergisi, 77-90.
[4] Emür, S. H., Onsekiz, D. 2007. Kentsel Yaşam Kalitesi Bileşenleri Arasında Açık ve Yeşil Alanların Önemi Kayseri/Kocasinan İlçesi Park Alanları Analizi. Dumlupınar Üniversitesi Sosyal Bilimler Enstitüsü 22, 367-396.

[5] Thompson, C. 2002, Urban Open Space in the 21st Century. Landscape and Urban Planning, $60,59-72$.

[6] Akdoğan, G. 1970, Yeşil Sahaların İklimsel Etkileri ve Şehir Planlamasındaki Fonksiyonları. Peyzaj Mimarlı̆̆ Dergisi, 1, 7-11.

[7] Elinç, H. 2011. Görsel Kalite Değerlendirmesi Yöntemi İle Antalya Alanya Kent Parklarının Değerlendirilmesi. Yüksek Lisans Tezi, Selçuk Üniversitesi Fen Bilimleri Enstitüsü, Konya.

[8] Polat, A. T. 2002, Kent Parkı Kavramı ve Konya İçin Örnek Bir Çalışma. Yüksek Lisans Tezi, Selçuk Üniversitesi, Konya.

[9] Karlıer, G. 2017. Kent Parkları Kavramı ve Bursa Kent Parklarında Kullanıcı Memnuniyetinin İrdelenmesi. Yüksek Lisans Tezi, Uludağ Üniversitesi Fen Bilimleri Enstitüsü, Bursa.

[10] Özdemir, A. 2009. Katılımcı Kentli Kimliğinin Oluşumunda Kamusal Yeșil Alanların Rolü; Ankara Kent Parkları Örneği. SDÜ Orman Fakültesi Dergisi, 1, 144-153.

[11] Chiesura, A. 2004. The Role of Urban Parks For The Sustainable City. Landscape and Urban Planning, 68, 129-138.

[12] Uzun, S. 2005. Kırsal Ve Kentsel Alanlardaki Parklarda Kullanıcı Memnuniyeti; Gölcük Ormaniçi Dinlenme Alanı Ve İnönü Parkı Örneği. Yüksek Lisans Tezi, Abant İzzet Baysal Üniversitesi Fen Bilimleri Enstitüsü Peyzaj Mimarlığı Anabilim Dalı, Bolu.

[13] Cetinkaya, G., Erman, A., Uzun, M. 2015. Rekreasyonel Amaçlı Park Kullanıcılarının Memnuniyet Ve Memnuniyetsizlik Faktörlerinin Belirlenmesi. International Journal of Human Sciences, 851-869.

[14] Bilgili, B. C. 2001. Tarihi Antakya Parkının Rekreasyon Alan Kullanımı Yönünden Değerlendirilmesi Ve Geliştirilmesi Üzerine Bir Araştırma. Yüksek Lisans Tezi, Fen Bilimleri Enstitüsü, Mustafa Kemal Üniversitesi, Hatay.

[15] Sugiyama, T., Carver, A., Koohsari, M. J. Veitch, J. 2018. Advantages of Public Green Spaces in Enhancing Population Health, Landscape and Urban Planning 178, 12-17.

[16] Karadeniz, Z. 2019. Peyzaj Tasarım Kriterleri Açısından Samsun Kent Parklarının İncelenmesi. Ordu Üniversitesi, Fen Bilimleri Enstitüsü, Peyzaj Mimarlığı Anabilim Dalı, Yüksek Lisans Tezi, Ordu. 
[17] Karakaya, N., Cengiz, T. 2019. Yaşam Kalitesinin Arttırılmasında Kent Parklarının Önemi: Eskişehir İli Örneğinde İncelenmesi. OPUS Uluslararası Toplum Araştırmaları Dergisi, $14(20), 1-1$.

[18] Kocalar, A. O. 2016. Ekolojik Farkındalığın Arttırılmasında Milli Parkların Rolüne İlişkin Öğrenci Görüşleri. Avrupa Bilim ve Teknoloji Dergisi, 5(9).

[19] Altuntaş, A. 2020. Siirt İli Tillo Tabiat Parkı'nın Kullanıcı Memnuniyeti Açısından Değerlendirilmesi. Avrupa Bilim ve Teknoloji Dergisi, (18), 359-367.

[20] Soydan, O. 2020. Kent Parklarının Kullanıcı Memnuniyetinin Niğde Örneğinde İncelenmesi. Avrupa Bilim ve Teknoloji Dergisi, (20), 712722.

[21] Vural H. 2020. Bingöl Halkının Yeșil Alan Kullanımı ve Kent Parkları Yeterliliklerinin Değerlendirilmesi. Journal of Bartın Faculty of Forestry, 22 (1), 79-90.

[22] Aksoy, Y., Akpınar, A. 2011. Yeşil Alan Kullanımı ve Yeşil Alan Gereksinimi Üzerine Bir Araştırma İstanbul İli Fatih İlçesi Örneği. İstanbul Ticaret Üniversitesi Fen Bilimleri Dergisi, 20, 81-96.

[23] Ayhan, A. Atabeyoğlu, Ö. 2020. Giresun Kenti Parklarında Kullanıcı Memnuniyeti, Kent Akademisi, 13(2), 305-314.

[24] Yücedağ, C., Kaya L. G., Aşıkkutlu, S. 2018. A Study on Usage of Urban Parks: Case of Pamukkale-Denizli, Turkey. The International Conference on Engineering and Natural Sciences (ICENS), 2-6 May, 78-82, Kiev, Ukraine.
[25] Kaya, L. G., Yücedağ, C., Aşıkkutlu, S., Şeker, E. 2019. Antalya Kentinde Dokuma Parkı Elemanlarının Kullanıcılar Tarafindan Değerlendirilmesi. 4th European Conference on Science, Art Culture, 18-21 April, 43-50, Antalya, Turkey.

[26] Köksaldı, E., Turkan, Z. 2020. Lefkoşa Suriçi Tarihi Dokusu Kentsel Peyzajında Bir Yeșil Alan:"Yiğitler Burcu Parkı". Yakın Doğu Üniversitesi Yakın Mimarlık Dergisi, 4(1), 23-33.

[27] Mahdavinejad, M., Abedi, M. 2011. CommunityOriented Landscape Design For Sustainability İn Architecture And Planning. International Conference on Green Buildings and Sustainable Cities, 337-344.

[28] Lee, H. 2007. A Study Of Use Patterns, User Satisfaction and Willingness to Pay for Off-Leash Dog Parks: Post-Occupancy Evaluations of Four Dog Parks in Texas and Florida. Texas A\&M University.

[29] Boyacı, E. 2010, Ülkemizde Kent Parkı İşlevlerini Belirleyen Etmenler, Yüksek Lisans Tezi, Ankara Üniversitesi, Ankara.

[30] Öztürk, B. 2004, Kentsel Açık ve Yeşil Alan Sistemi Oluşturulması: Kayseri Kent Bütünü Örneği, Doktora Tezi, Ankara Üniversitesi, Ankara.

[31] Mcpherson, E. G. 1994, Cooling Urban Heat Islands with Sustainable Landscapes. In: The Ecological City: Preserving and Restoring Urban Biodiversity. Eds: Platt RHR, Rowan A.; Muick, Pamela C.; eds. Amherst, Massachusetts: University of Massachusetts Press, 151-171. 